\title{
Implementation of the national school nourishment program in the Brazilian Federal institution of Education of Bahia State
}

\author{
Katia de Fatima Vilela ${ }^{1,2^{*}}$ (D) Alair Ferreira de Freitas ${ }^{1}$ (D) Rodney Alves Barbosa ${ }^{1,2}$ (iD \\ Rafael Junior dos Santos Figueiredo Salgado ${ }^{3}$ iD
}

1Programa de Pós-graduação em Extensão Rural, Universidade Federal de Viçosa (UFV), 36570-900, Viçosa, MG, Brasil. E-mail: katia.vilela@ifmg.edu.br. ${ }^{*}$ Corresponding author.

${ }^{2}$ Instituto Federal de Minas Gerais (IFMG), São João Evangelista, MG, Brasil.

${ }^{3}$ Programa de Pós-graduação em Administração, Universidade Federal do Rio Grande do Norte (UFRN), Natal, RN, Brasil.

ABSTRACT: The Brazilian National School Nourishment Program (PNAE) is one of the strongest public policies of food and nutrition in the world. Besides guaranteeing free and high-quality meals to students in the basic public educational system, the PNAE also establishes that at least $30 \%$ of the resources passed on to the municipalities by the federal government should be destined for the acquisition of foodstuffs from family agriculture. However, the budget execution of the PNAE by Federal Institutes of Education has been challenging and limiting regarding the practicability of the acquisition of food from family farmers. In this study, we provided empirical evidence that constitutes an essential analytical approach still little explored in the literature, but capable of revealing operational barriers to the implementation of the program. The objective of this study was to describe the implementation and to understand the difficulties perceived by the agents responsible for the operationalization of the PNAE in the campuses of the Federal Institute of Education, Science and Technology of Bahia State (IF Baiano). Therefore, we collected secondary data from institutional documents, whereas the primary data were obtained by semi-structured interviews performed in ten campuses of IF Baiano and the rectory. We observed that in some years, the budget destined to PNAE returned without implementation, evidencing flaws in the resources management. Thus, we concluded that some challenges need to be overcome before the implementation of the Program in these Federal Institutions.

Key words: public policy, government procurement, school feeding.

A implementação do programa nacional de alimentação escolar na instituição federal de ensino da Bahia

\begin{abstract}
RESUMO: Mundialmente existem distintos modelos de Programas voltados para a alimentação escolar, dentre esses, o Brasil ganha destaque com o Programa Nacional de Alimentação Escolar (PNAE). Trata-se de uma das políticas públicas de alimentação e nutrição expressiva, quando comparado com os demais países. O PNAE garante alimentação gratuita e de qualidade aos estudantes da educação básica pública e, também estabelece que, no mínimo, 30\% dos recursos repassados aos municípios pelo governo federal deverão ser utilizados na aquisição de gêneros alimentícios da agricultura familiar. No entanto, a execução orçamentária do PNAE, por parte das escolas denominadas Institutos Federais, tem se mostrado complexa e limitante à operacionalização da compra de alimentos da agricultura familiar. Essa evidência empírica constitui, neste trabalho, importante enfoque analitico, ainda pouco explorado pela literatura, mas capaz de desvelar barreiras operacionais à implementação do PNAE. O objetivo deste estudo foi descrever a execução orçamentária do Programa e compreender as dificuldades percebidas pelos agentes responsáveis pela operacionalização do PNAE nos Campi do Instituto Federal de Educação, Ciência e Tecnologia Baiano (IF Baiano). A metodologia utilizada foi a coleta de dados secundários, por meio de documentos institucionais. Os dados primários foram coletados por meio de entrevistas semiestruturadas, em dez Campi do IF Baiano e na reitoria. Como resultados verificou-se que o orçamento do PNAE, em alguns anos, foi devolvido sem execução, o que demonstra entraves na operacionalização dos recursos. Concluiu-se que alguns obstáculos precisam ser sanados para que o programa seja efetivado nessas instituições federais.

Palavras-chave: política pública, compras governamentais, alimentação escolar.
\end{abstract}

\section{INTRODUCTION}

Several countries adopt distinct school nourishment programs, but all of them share the common concern to provide food for students enrolled in basic or primary school education in public institutions (BELIK \& SOUZA, 2009). In general, these programs have a fragile implementation and does not reach their target population, which are the people in most need of social policies. Considering that, BELIK, \& SOUZA (2009) conducted a reflective study on school nourishment programs in Latin America, where they state that Brazil is a good reference for other countries, since the Brazilian 
National School Nourishment Program (PNAE, in Portuguese) is the only one that has an advanced design with universal coverage.

Few other countries in the world have a wide-ranging school nourishment program. In Chile and the United States, school meals are available only for students who declare poverty. In Uruguay, the government established that the meals vary according to the type of school and the district, with difference between urban and rural locations (BELIK \& SOUZA, 2009). The authors (BELIK \& SOUZA, 2009) emphasized that while some countries do not have national coverage for school nourishment programs, others do not serve students every school day, and others do not have permanent sources of financing based on legislation.

In Brazil, the PNAE is one of the oldest federal government interventions for school nourishment in the context of social policies (PIPITONE et al., 2003; SANTOS et al., 2007). Several significant changes occurred during the history of the PNAE, markedly the advent of Law $11.947 / 2009$ and Resolution 26/2013. From these regulations, the procurement of foodstuffs began to be executed preferably in the municipality where the schools are located. Moreover, they ensure that at least $30 \%$ of the resources passed through the government agency National Education Development Fund (FNDE, in Portuguese) are destined for school feeding and that these food supplies come from family farmers or their organizations (CHAVES et al., 2009; GONÇALVES et al., 2015).

The PNAE also aims to provide at least $15 \%$ of the daily food and nutritional needs for students in public elementary schools during their school time, contributing to their growth, development, school performance and formation of healthy eating habits (OLIVEIRA et al., 2017). The success of the PNAE in Brazil promotes a reconnection between production and consumption. Several countries have recognized and begun to disseminate the Brazilian experience as an example of good practices, and the strategies are being replicated and adapted in Europe, Africa, Latin America and, more recently, the Caribbean (SCHNEIDER et al., 2016).

In the Federal Institutes of Education (IFs), the financial resources from PNAE are decentralized by the FNDE annually, usually in the first quarter of the year, considering the number of students enrolled in the previous year (Table 1), contemplating students in full time courses and those enrolled in the EJA program (Education for young and adults) (HIRATA et al, 2017). Moreover, it is important to mention that these resources are complementary, i.e., they are added to the funds of the executing agencies, and should not replace the responsibilities of these entities concerning the application of own resources and their budgets for school nourishment (HIRATA et al, 2017)

Another innovation of the PNAE is the legislation of the Brazilian public acquisitions. Until then, all purchases had obligatorily to follow the legal precepts of isonomy and competition. The PNAE sets a historical precedent for suppliers characterized as family farmers, by suspending the bidding process.

During the Brazilian historical context, several practices sought to integrate rural development, family agriculture, food security, and government procurement. Therefore, COIMBRA et al. (1982) argue that this traditional course of the program began in 1908, with similar experiences to the PNAE, when with the aid of a nonprofit entity linked to Freemasonry, denominated Selective Humanitarian Charity, occurred the free food supply to the public schools, the historical evolution of PNAE was presented by PEIXINHO (2013), and will not be discussed in this study.

In Brazil, there is a vast scientific production on the PNAE, which allows us to finetune the study on this theme. However, during the mapping, we noticed that most of the articles that deal with the program prioritize the discussion on the following topics:

Table 1 - Additional value per student category for school nourishment from National Education Development Fund (FNDE) and National School Nourishment Program (PNAE) to the Federal Institute of Education of Bahia State (IF Baiano).

\begin{tabular}{lc}
\hline Offer category & Money per student enrolled (in Brazilian Reais) \\
\hline Students in subsequent education & 0.32 \\
Students from Young and Adult Education (EJA) & 0.32 \\
Students enrolled in full time courses with minimum time of 7h. & 1.07
\end{tabular}

Source: Adapted from Art. 1 from the Resolution CD/FNDE number 01/2017. 
i) the insertion of the nutritionist (CORRÊA et al., 2017; PEDRAZA et al., 2018). ii) the acquisition of food supplies from familiar agriculture (AGUIAR \& CALIL, 2016); MIRANDA \& GOMES, 2016; SCHNEIDER etal., 2016; PEDRAZAetal., 2018).iii) the implementation of School Nourishment Councils (ROJAS-BUVINICH, 2014). iv) the preparation of menus (FORMIGA et al., 2015, PEDRAZA et al., $2018)$; v) the financial resources allocated to the PNAE (MELO et al. 2016, PEDRAZA et al., 2018); and vi) the lack of information about the Program (RIBEIRO et al., 2013, GRISA \& SCHNEIDER, 2014). These approaches mostly investigate the implementation of the PNAE at the municipal and state level, or analyze the program's trajectory (PEIXINHO, 2013), leaving a gap regarding the execution of PNAE in federal institutions.

The study of the implementation of the PNAE in the Federal Institutes is relevant because the IFs are present in all Brazilian states, with 588 teaching units, and 758,196 students enrolled in basic public education (PNP, 2018). In addition, the implementation of the program in FIs has different aspects between municipal and state schools, such as the decentralization of the resource in a single installment in the first quarter of the year of the FNDE to the rectory, the execution of the resources internally in the campuses, the Federal Institutes are educational, administrative and patrimonial autonomies, different from the municipal executing agencies, and also from the state executors, the Federal Institutes have the extension department, most IF campuses have rural ballast, approaching family farmers.

In the IFs, the initiatives of the program go beyond complying with normative obligations. In addition to guaranteeing quality food for students, it encourages family agriculture to organize, professionalize, generate income and promote economic actions, and support local development (BRASIL, 2008).

Despite the fragmentation, the potential for PNAE implementation and consequent food purchases from family agriculture and support for regional development, there are still few studies in the literature that analyze the PNAE for IFs. Figure 1 shows in a timeline the budgets decentralized by FNDE for all 38 existing IFs in Brazil and their respective returns (without implementation).

Although, the decentralized volume by the PNAE for the IFs had a significant increase of $117.53 \%$ in the period between 2013 and 2017, the budget returned remained high, with an average of $50.48 \%$ (Figure 1). To understand the obstacles concerning the budget implementation, it is necessary

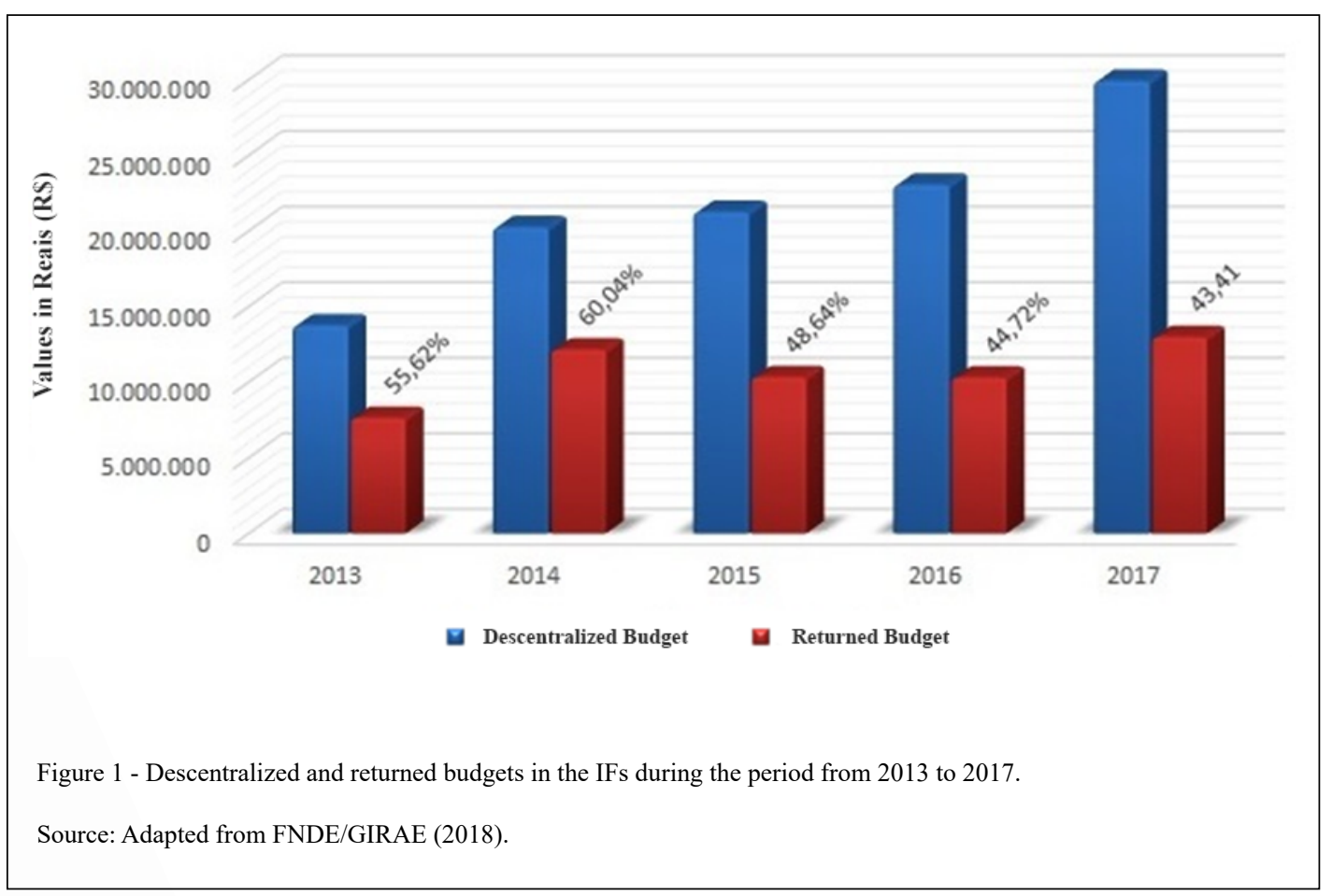

Ciência Rural, v.49, n.9, 2019. 
to perform a close study with the managers responsible for executing the PNAE in these federal institutions.

The objective of this study was to describe the implementation and to understand the difficulties perceived by the agents responsible for the operationalization of the PNAE in the campuses of the Federal Institute of Education, Science and Technology of Bahia State (IF Baiano). We hypothesized that the Federal Institutes may have impediments related to budget execution, bureaucratic aspects, human and structural resources, as well as to the productive, organizational and logistic limitations of family agriculture (MALUF, 2017). Consequently, the policy would not address its initial role in creating an institutional market for family agriculture and would prevent it to become an instrument for accessing healthy food for children at primary school.

\section{MATERIAL AND METHODS}

The present study consisted of an exploratory analysis since the topic regarding Brazilian Federal Institutions of Education is still very scarce in the literature. For the report, we evaluated ten campuses of IF in Bahia state, Brazil. The secondary data were obtained by consulting institutional documents, especially the synthesis reports on budget implementation generated through the Treasure Management system, which is a business intelligence platform for consulting the budget and financial implementation of the Federal government. These data were extracted on 27/11/2017.

The data for national implementation of the program in the IFs were obtained on 14/06/2018 in response to an official inquiry to the Coordination of Financial Execution for Nourishment (COEFA, in Portuguese) and the PNAE coordination through electronic spreadsheets containing the data from 38 IFs from 2013 to 2017. The quantitative content of the secondary data provided by IF Baiano and FNDE were released in Excel spreadsheets for further analysis of the program's executions. This compilation of data occurred concomitantly with the interviews. We obtained the primary data by sending a structured questionnaire by e-mail to the IFs employees involved with the PNAE in the campuses and the rectories. The director of administration and planning, the director of planning and budget director, two general managers, a nutritionist, the head of the bidding unit, two administrative assistants, the head of the campus office and an accountant, totaling eight employees, distributed in eight campuses out of ten analyzed, were interviewed, in addition to two representatives of the rectory. The questionnaires were applied in November 2017, and the questions are presented in the supplementary material $\mathrm{S} 1$.

\section{Overview of public procurement of family agriculture in the IF Baiano}

The IF Baiano comprises the former Federal Agrotechnical Schools and the Regional Agricultural Schools of Ceplac (EMARC, in Portuguese). It consists of different campuses and rectory, present in 15 cities in Bahia State, Brazil. For this study, we selected the campuses that were able to execute the PNAE, and their locations are presented in figure 2.

The campuses of Alagoinhas, XiqueXique, Itaberaba, and Serrinha are not included in the analysis, since they were at the implantation stage, with no operations in the PNAE. The campus of Salvador was not included because only the Rectorate of the IF Baiano functions in that location.

\section{RESULTS AND DISCUSSION}

The IF Baiano contains 13,324 students enrolled in basic education, and it offers 194 courses in various campuses spread across several regions of Bahia (PNP, 2018). The IF is a potential buyer of family agriculture via PNAE. However, the existence of several discrepancies concerning the execution of the PNAE was observed in the literature and empirically (PEDRAZA et al., 2018).

Bahia is the Brazilian State with the highest number of family farmers, with 665,831 , or $15.2 \%$ of the national total of family farmers (FRANÇA et al., 2009). These data reinforce the relevance of public policies for the purchase of food supplies as a strengthening of family agriculture and guarantee access to healthy and adequate meals, according to the perspective of human rights and health promotion (BELIK, 2003).

In addition to the importance of family agriculture in Bahia state, we emphasized that there is space to implement different policies to strengthen family agriculture and combat hunger and poverty in the Brazilian regions, especially in the North and Northeast. These places contain the highest levels of poverty in the country, and where the frequency of the poor is systematically higher in rural areas than in urban areas (MONTEIRO, 2003).

We investigated if family farmers in Bahia State access the program individually or through organizations, which showed that $33 \%$ of the participants in public calls in the IF Baiano come 


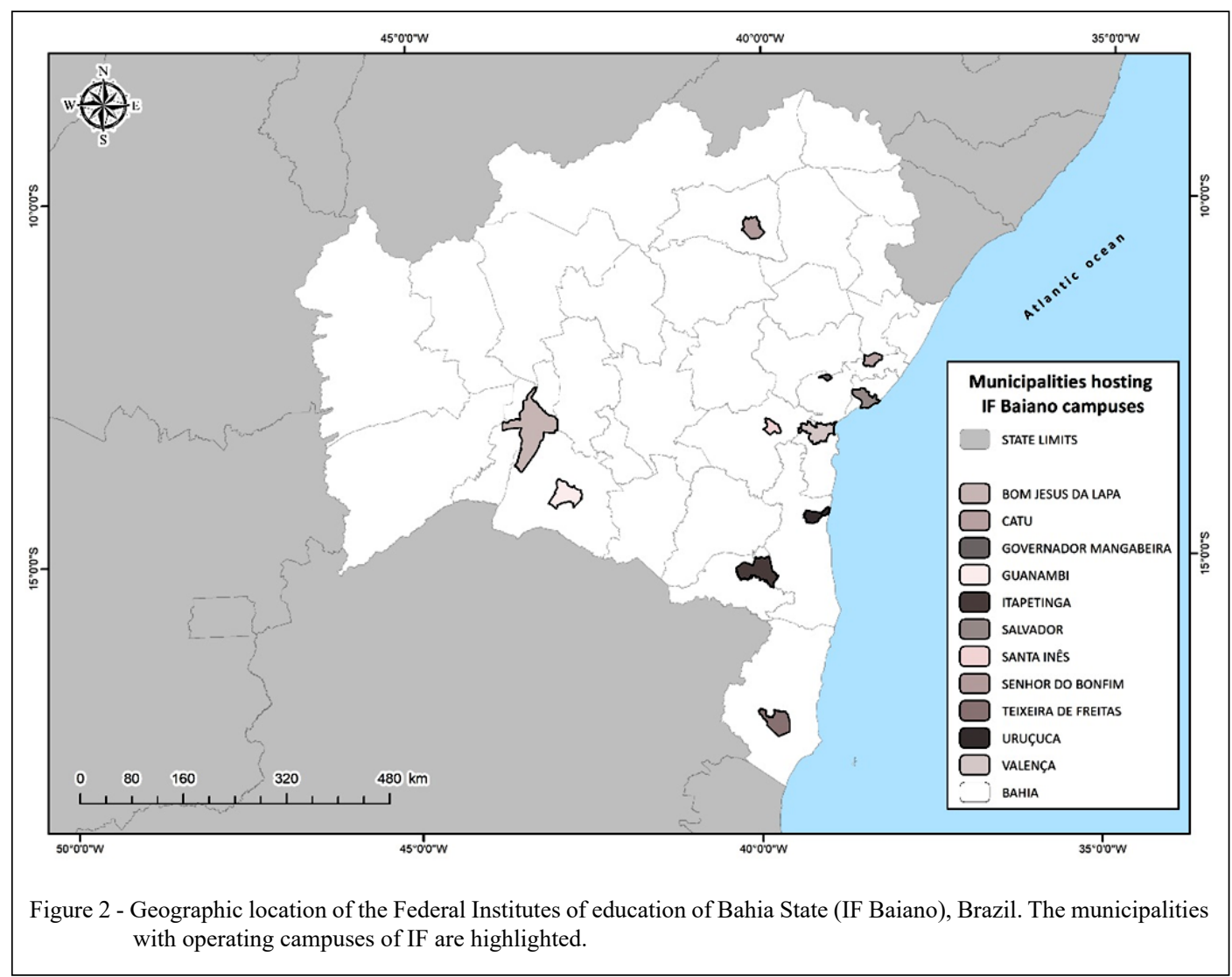

from associations, $33 \%$ from cooperatives, $20 \%$ are individual family farmers, $7 \%$ are from social movements and $7 \%$ are from rural workers' unions.

The majority of family farmers are organized in cooperatives or associations, indicating that the PNAE can become an essential instrument for strengthening cooperative and associative activities among family farmers. Strengthening of economic organizations tends to allow the productive inclusion of family farmers, especially those who need support to overcome poverty in the North and Northeast regions of Brazil (MONTEIRO, 2003).

\section{Commitment, Settlement and Payment - the case of} PNAE in the IF BAIANO

Commitment is the amount that the public agency reserves to make a planned payment, and occurs after the signing of a service contract. The settlement is the second stage of budget spending. It consists of the verification of the right acquired by the creditor, and is based on the titles and supporting documents of the respective credit. It is important to highlight that the settlement of expenses with supply or services rendered will be based on the contract, adjustment or agreement (TESOURO NACIONAL, 2018).

The payment is the last stage of public expenditure and is characterized by the issue of the check or bank order in favor of the creditor, i.e., payment of the expenses incurred (TESOURO NACIONAL, 2018). Table 2 presents the implementation of the budget of the PNAE in the IF Bahia between 2014 and 2017.

From 2014 to 2017 the decentralized amount destined to the PNAE in the IF Baiano increased. The variation of commitment and return percentages indicated the existence of obstacles in the process of public call that need to be verified in the IF Baiano and the campuses who received the budget for implementation.

Table 3 presents the PNAE implementation scenario and the respective amounts committed, settled and paid. Despite the increase in the number of campuses implementing the program, we observed that the oscillation of the committed values indicates that the purchases from family agriculture still find barriers in its implementation process.

Ciência Rural, v.49, n.9, 2019. 
Table 2 - Decentralized and returned budget from PNAE to Federal Institution of Education of Bahia State, Brazil, during the period between 2014 to 2017. Values are presented in Brazilian reais (R\$).

\begin{tabular}{|c|c|c|c|c|}
\hline \multirow[t]{2}{*}{ Orçamento do PNAE } & 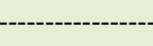 & - & - & -------------' \\
\hline & 2014 & 2015 & 2016 & 2017 \\
\hline Decentralized (R\$) & $273,660.00$ & $710,740.00$ & $715,660.00$ & $720,200.00$ \\
\hline Commited (R\$) & $250,389.17$ & $618,606.77$ & $473,077.04$ & $657,707.35$ \\
\hline Returned (R\$) & $23,270.83$ & $92,133.23$ & $242,582.96$ & $62,492.65$ \\
\hline Commited $(\%)$ & $91.50 \%$ & $87.04 \%$ & $66.10 \%$ & $91.32 \%$ \\
\hline Returned (\%) & $8.50 \%$ & $12.96 \%$ & $33.90 \%$ & $8.68 \%$ \\
\hline
\end{tabular}

The low execution in 2014 can be attributed to the recent nature of the policy and the managers' lack of experience in carrying out this type of public procurement (ASSIS et al., 2017; SALGADO, 2016). The institute has a high average of committed values, approximately $83.99 \%$; however, the commitment is only an indication of purchase, and may not be effective.

The average amount settled and paid, $45.83 \%$ and $35.11 \%$, respectively, indicates that despite the high volume involved, it does not translate into income for family agriculture, given the low amounts paid to family farmers. According to the initial hypothesis, the barriers to purchases may relate to budgetary aspects, management, and bureaucracy present in the institution, as well as productive, logistic aspects and disarticulation of family agriculture in the region.

In budget terms, it is important to note that in 2014, 2015 and 2016, the decentralization of PNAE resources only occurred in the second half of the year, jeopardizing the publication and implementation of public procurement in that year. It is evident that the delay in the release of the financial capital from the federal government may affect the payment of the expenses settled. This delay in payments causes the producer/organization to stop responding to new orders, which explains the low settlement of specific commitments. Thus, we suggested that PNAE payments should be treated as personal payment expense, having the resources available at the time of settlement.

\section{Processes of public calls in the IF Baiano}

The purchase process by PNAE is still bureaucratic, involving different stages and sectors. The chronological order of each stage, as reported by HIRATA et al. (2017), is 1) Appointment of the special committee for family agriculture procurement (CECAF). 2) Identification of family farmers and local producers. 3) Establishment of the menu. 4) Basic project. 5) Prices quotation. 6) Formalization of the process. 7) Public announcement. 8) Budget/ authorization. 9) Legal analysis. 10) Publication of the public call. 11) Receipt of the proposed sales. 12) Public session of judgment. 13) Publication of the judgement. 14) Receiving samples. 15) Homologation. 16) Disclosure of the waiver of bidding System of Electronic Disclosure of Purchases and Procurements (SIDEC, in Portuguese) and Integrated System of Management of General Services (SUASG, in Portuguese). 17) Note of commitment. 18) Issue of the contract.

These 18 steps demonstrated the complex process of PNAE's purchasing, even without the need for bidding. Other institutional barriers may be the shortage of qualified personnel, the delivery schedule, which does not meet the harvest/off-season periods, and the late payments to farmers.

In addition to the barriers linked to institutional aspects, the difference between decentralized/committed budget and what is actually paid to the family farmer may be due to the limitations of family agriculture, according to the interviewee, identified as JE.: "The campuses have difficulties executing the PNAE budget, because small producers do not attend to participate in public calls".

Other obstacles faced in the implementation of the PNAE public call are: i) limited logistic capacity of family farmers (27\%); (ii) insufficient diversity in family farming products $(27 \%)$; iii) lack of documentation of family farmers/organizations $(20 \%)$; iv) reduced technical capacity to meet the requirements of the process $(20 \%)$; and difficulty in meeting the specifications of health legislation $(6 \%)$.

These results are compatible with the findings by TURPIN (2008), and DINIZ et al., (2016), who observed the barriers faced by family farmers in providing food for schooling are: to meet the demanded volume, lack of professionalization, compliance with sanitary specifications and, above all, logistic difficulties. 
Table 3 - Overview of the PNAE implementation in the Federal Institute of Bahia State, Brazil, from 2014 to 2017.

\begin{tabular}{|c|c|c|c|c|c|c|c|c|c|c|c|c|}
\hline \multirow[t]{2}{*}{ Campuses } & \multicolumn{3}{|c|}{---------------2014---------------- } & \multicolumn{3}{|c|}{----------------2015---------------- } & \multicolumn{3}{|c|}{---------------2016-------------- } & \multicolumn{3}{|c|}{ 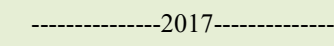 } \\
\hline & Commited & Settled & Paid & Commited & Settled & Paid & Commited & Settled & Paid & Commited & Settled & Paid \\
\hline $\begin{array}{l}\text { Bom Jesus } \\
\text { da Lapa }\end{array}$ & - & - & - & - & - & - & - & - & - & $\begin{array}{c}21,960 . \\
00\end{array}$ & $\begin{array}{c}4,560 . \\
74\end{array}$ & $\begin{array}{l}4,560 . \\
74\end{array}$ \\
\hline Valença & - & - & - & $\begin{array}{c}74,031 \\
50\end{array}$ & $\begin{array}{c}7,283 . \\
00\end{array}$ & 0.00 & $\begin{array}{c}73,698 \\
85\end{array}$ & 0.00 & - & $\begin{array}{c}79,221 \\
17\end{array}$ & 0.00 & - \\
\hline Itapetinga & - & - & - & $\begin{array}{c}64,407 \\
00\end{array}$ & $\begin{array}{c}5,197 . \\
79\end{array}$ & $\begin{array}{c}5,197 . \\
79\end{array}$ & $\begin{array}{c}57,098 \\
60\end{array}$ & $\begin{array}{c}9,105 . \\
94\end{array}$ & $\begin{array}{c}9,105 . \\
94\end{array}$ & $\begin{array}{c}54,961 \\
80\end{array}$ & 0.00 & - \\
\hline $\begin{array}{l}\text { Teixeira de } \\
\text { Freitas }\end{array}$ & - & - & - & - & - & - & - & - & - & $\begin{array}{c}49,645 \\
64\end{array}$ & $\begin{array}{c}2,966 . \\
50\end{array}$ & $\begin{array}{l}2,966 . \\
50\end{array}$ \\
\hline Urucuca & - & - & - & $\begin{array}{c}99,589 \\
65\end{array}$ & $\begin{array}{c}99,589 . \\
65\end{array}$ & $\begin{array}{c}99,589 . \\
65\end{array}$ & $\begin{array}{c}56,826 \\
00\end{array}$ & $\begin{array}{c}44,370 . \\
97\end{array}$ & 0.00 & $\begin{array}{c}65,099 \\
28\end{array}$ & 0.00 & - \\
\hline $\begin{array}{l}\text { Gov. } \\
\text { Mangabeira }\end{array}$ & - & - & - & $\begin{array}{c}2,123 \\
10\end{array}$ & $\begin{array}{c}2,123 \\
10\end{array}$ & 0.00 & - & - & - & $\begin{array}{c}20,860 \\
00\end{array}$ & $\begin{array}{c}8,826 . \\
15\end{array}$ & $\begin{array}{l}7,853 . \\
55\end{array}$ \\
\hline Santa Inês & - & - & - & $\begin{array}{c}95,570 \\
65\end{array}$ & $\begin{array}{c}11,863 \\
80\end{array}$ & 0.00 & - & - & - & $\begin{array}{c}100,314 \\
88\end{array}$ & 0.00 & - \\
\hline $\begin{array}{l}\text { Senhor do } \\
\text { Bonfim }\end{array}$ & $\begin{array}{c}35,898 \\
89\end{array}$ & $\begin{array}{c}35,898 \\
89\end{array}$ & 0.00 & $\begin{array}{c}88,998 \\
58\end{array}$ & $\begin{array}{c}88,998 \\
58\end{array}$ & $\begin{array}{c}86,515 \\
79\end{array}$ & $\begin{array}{c}95,499 \\
97\end{array}$ & $\begin{array}{c}87,421 . \\
97\end{array}$ & $\begin{array}{c}87,421 . \\
97\end{array}$ & $\begin{array}{c}89,410 \\
60\end{array}$ & 0.00 & - \\
\hline Guanambi & $\begin{array}{c}50,772 \\
39\end{array}$ & $\begin{array}{c}13,968 \\
84\end{array}$ & 0.00 & $\begin{array}{c}58,648 \\
18\end{array}$ & $\begin{array}{c}14,665 \\
16\end{array}$ & $\begin{array}{c}14,665 \\
16\end{array}$ & $\begin{array}{c}58,945 . \\
99\end{array}$ & $\begin{array}{c}9,803 . \\
67\end{array}$ & 0.00 & $\begin{array}{c}36,157 \\
70\end{array}$ & $\begin{array}{c}10,077 \\
77\end{array}$ & $\begin{array}{l}8,611 . \\
77\end{array}$ \\
\hline Catu & $\begin{array}{c}40,988 \\
99\end{array}$ & $\begin{array}{c}24,434 \\
15\end{array}$ & $\begin{array}{c}14,277 \\
76\end{array}$ & $\begin{array}{c}134,224 \\
10\end{array}$ & $\begin{array}{c}124,896 \\
35\end{array}$ & $\begin{array}{c}104,778 \\
68\end{array}$ & $\begin{array}{c}131,007 \\
63\end{array}$ & $\begin{array}{c}130,166 . \\
93\end{array}$ & $\begin{array}{c}130,166 . \\
93\end{array}$ & $\begin{array}{c}140,076 \\
28\end{array}$ & $\begin{array}{c}58,593 \\
47\end{array}$ & $\begin{array}{l}58,593 . \\
47\end{array}$ \\
\hline Reitoria & $\begin{array}{c}122,728 \\
90\end{array}$ & $\begin{array}{c}60,134 . \\
09\end{array}$ & $\begin{array}{c}60,134 . \\
09\end{array}$ & $\begin{array}{c}1,014 . \\
01\end{array}$ & 0.00 & - & - & - & - & - & - & - \\
\hline \multirow[t]{2}{*}{ Total } & $\begin{array}{c}250,389 \\
17\end{array}$ & $\begin{array}{c}134,435 \\
97\end{array}$ & $\begin{array}{c}74,411 \\
85\end{array}$ & $\begin{array}{c}618,606 \\
77\end{array}$ & $\begin{array}{c}354,617 \\
43\end{array}$ & $\begin{array}{c}310,747 . \\
07\end{array}$ & $\begin{array}{c}473,077 \\
04\end{array}$ & $\begin{array}{c}280,869 \\
48\end{array}$ & $\begin{array}{c}226,694 \\
84\end{array}$ & $\begin{array}{c}657,707 \\
35\end{array}$ & $\begin{array}{c}85,024 . \\
63\end{array}$ & $\begin{array}{l}82,586 . \\
03\end{array}$ \\
\hline & $91.50 \%$ & $53.69 \%$ & $29.72 \%$ & $87.04 \%$ & $57.33 \%$ & $50.23 \%$ & $66.10 \%$ & $59.37 \%$ & $47.92 \%$ & $91.32 \%$ & $12.93 \%$ & $12.56 \%$ \\
\hline
\end{tabular}

The responses reported in the interviews corroborate this information, especially regarding the limited participation and lack of diversity of products from family agriculture. The interviewees, identified by their initials, reported that: i) "sometimes it is the limitation of products, since what we need the most is not offered by family farming" - MA; ii) "Limitation of products, few associations of farmers, few cooperatives, lack of dissemination of PNAE for family farmers, causing low participation of farmers" - JV; iii) "Meet the current legislation" - RI.

The limitations pointed out by managers are interrelated with several limiting factors portrayed in the literature, such as the lack of technical assistance and articulation with other public policies that could stimulate and boost institutional purchasing programs (GRISA et al., 2011). The lack of social control mechanisms in many municipalities (CARVALHO, 2007), the lack of sanitary inspection services that limit the commercialization mainly of products of origin and the operational difficulties (high bureaucracy, late payment, internet access, etc.) (RESENDE et al., 2012, CIRINO et al., 2014).
These factors, added to the lack of knowledge on the existence and institutionality of the program, the need to document the ownership of land to access the Pronaf Declaration of Aptitude (DAP), the lack of infrastructure (roads, means of production, electricity, etc.) and the high demand for social organization, tend to limit and even prevent the access of farmers to the program and; consequently, the implementation of government purchases of family agriculture.

Conversely, family farmers who are able to participate in public calls face difficulties regarding to the lack of logistics capacity to meet the demands of the process. The obstacles include the high cost of transport and packaging for highly perishable foods, lack of product diversity, lack of documentation and technical capacity of the farmer to meet the bureaucratic requirements of access to the process, informality of the agribusiness, as well as the disarticulation between program managers and family farmers, as reported by the program managers interviewed "MA, JV, JE, CS "in the IF Baiano.

Several researchers described the difficulties of family farmers to access or even stay in the Program at the municipal and/or state level. 
Thus, further studies are necessary to investigate if the problems faced by the farmers who participate in the PNAE together with the IF Baiano are the same obstacles reported by the producers that access the Program at the municipal or state level. On-site interviews with family farmers could provide the answers and improve the discussion on this topic; however, it consists of a limitation of this research that should be addressed in future studies.

Furthermore, we observed the absence of the FNDE in the orientation, implementation of the Program and execution of the PNAE budget for the IFs, since the training of the servers was, in most cases, provided by IF Baiano, as reported by respondents.

Based on the limitations, it is imperative to create partnerships between the local protagonists and the organizations that execute the PNAE. Since the Program requires a greater professionalization of rural workers, it is necessary to establish networks of partnerships between farmers, public technical assistance, managers of the IFs and entities to support family agriculture, to articulate the actions related to the purchase of family agriculture and to strengthen production and marketing processes.

\section{The institutional procurement market and the} development

In this section, we present the discursive issues related to this field research. Regarding the main advantages of the PNAE budget for the campuses, we obtained the following responses: i) "Targeting and growth of the local economy" - MA, JV; CS ii) "To promote trade in the region, to bring the Institute closer to small producers, cooperatives and farmers associations" - JV, RI, MA.

It is evident that its executors recognize the relevance of the program in the IF Baiano, and they see it as a dramatic intervention of the State that fosters local development. This perception is corroborated by MELÃO (2012), who studied sustainable products in school nourishment in the state of Paraná, and reported that the PNAE is an essential public policy instrument for local sustainable development.

In addition, the responses illustrate the importance of the PNAE to complement the school feeding budget in IFs, also contributing to guarantee food security by encouraging healthy eating practices, offering adequate food in quality, quantity, and regularity. Similarly, ZIMMERMANN and FERREIRA (2008) relate school food security to increased school attendance and performance and reduced school dropout. Moreover, the Program respects the local habits and cultural diversity of students.
When asked about the actions to increase the efficiency of the PNAE budget, they mentioned: i) To expand the possibilities of use, including other products not specified by the legislation - MA; ii) To promote technical training and seminars in the regions, disseminating the objectives of the PNAE and its benefits to the local population - JV, iii) Debureaucratize the process, increase the limit of sales value per family farmer/organizations. - RI).

It is consensual that the PNAE is a milestone in policies aimed food security and nutrition and the strengthening of family agriculture. However, the interviewees agree and acknowledge that the excess of bureaucracy for the participation of the family farmers in this program reduces the effectiveness of its operationalization.

Regarding the role of the PNAE in fostering the development of the rural environment, we obtained the following responses: "Due to the limitation and lack of support to the rural communities, the program's resource, above all, provides more dignity to the community, increasing the income of the farmers "- MA, JV, JE, CS.

Although, the respondents report the potential of the PNAE for rural development, we observed that the program cannot take account the sustainable local development in these territories, since there are different limitations in the implementation process, which restricts their contribution as the public policy of strengthening family farming and promoting rural development.

The interviewees also reported other arguments regarding what they considered to be of great importance for the implementation of the PNAE, as listed: i) The IF Baiano, as a field-oriented institute, should promote courses and dissemination of PNAE in the region, answering questions of the regional community - XA. ii) One of the major obstacles to the implementation of the PNAE budget is the non-participation of small family farmers and cooperatives in the processes. When a cooperative appears, it has difficulty in delivering the goods.-

Some cases the cooperative does not have working capital. "Therefore, if the government delay the release of the money, the cooperative cannot deliver the next order, since they comprise small producers who also do not have working capital. Thus, they end up either not delivering the orders or requesting cancellation of the contract due to inability to hand over the products, and financial inability to remain financially viable until the federal government payment becomes available"- KA. This empirical evidence confirms that the problem 
raised by COSTA (2015) persists, noting that the IFs present difficulties regarding compliance with article 14 of Law 11,947 / 2009.

\section{CONCLUSION}

The evolution of values and the implementation of the PNAE in the IF Baiano in the analyzed years are remarkable. However, some obstacles must be overcome to increase the participation of the family farmers in public calls. Results pointed to a disarticulation between IF Baiano's campuses and family farmers, since, even to foster family agriculture, there are several obstacles in the institutional and in the capacity of family agriculture levels, which impede the active participation of family farmers in public calls.

In addition to the mentioned factors, the findings encourage future studies seeking to investigate the institutional factors responsible for non-payment of the expenses. Several factors act as obstacles to the process, such as the breach of contract by both the Institute and the farmer, products that did not meet the needs of the campuses, elaboration of menus with items that do not match the production of the region, among several other factors, that can only be validated within in loco research.

Difficulties are minimized by providing public technical assistance to family farmers and organizations since access to information and technology is still restricted to these communities. Thus, the IFs could offer the training through their extension programs. Another alternative is the strengthening of associations and cooperatives of family farmers so that they can participate in the processes and meet the demand of the institutes, which includes the structuring of administration, production, logistics, financial, accounting and legal sectors.

Another point that can potentially improve the implementation of the program is to reduce the time of the federal government in releasing the financial resource to pay the settled expenses, thus reducing the need for working capital by family farmers and their organizations, or the creation of a line working capital, including the PNAE suppliers.

Results presented in this study are very relevant for the improvement of the PNAE, as well as for the maintenance of food and nutritional security of the students assisted by the IF Baiano and for the strengthening of family agriculture. This study can be used as a tool for discussions and articulations that guide the execution and enhancement of PNAE in these educational spaces.
The importance of the PNAE for rural development is recognized by the authors who discuss the subject, as well as by those who execute the budgets and by those who are directly involved in the public calls. It is also important to highlight that the study, in addition to contributing to the improvement of the PNAE, since starting with initiatives such as Decree No. 8,473, dated June 22, 2015, present in the Harvest Plan of Family Agriculture 2015/2016, the organs of the Union that receive resources to purchase food are obliged to buy at least $30 \%$ of the food from family agriculture.

As limitations of this study and suggestions for future research, we emphasized the need to verify in loco the public calls. In addition, it is essential to investigate the existence of social networks composed by an intersectoral team for implementation of the Program in the IFs and to interview family farmers and their organizations, to have a perception of these social protagonists regarding the execution of the PNAE by the IFs.

We also encouraged future studies focusing on the institutional and relational approach to PNAE implementation since the Program is part of social construction, with the interaction between different actors internal to the IFs (employees and administrative technicians), and external (articulating entities and family farmers), with different relational formats that interfere positively or negatively with the results of the Program.

Thus, further research is required considering not only the perspectives of public policy or family agriculture but also aligning public policy with the actors involved in the implementation of the Program, that is, program managers and family farmers. This approach at the implementation of public policies, taking into account the relational dynamics of all the actors involved, could help managers and policymakers in the improvement of social programs.

\section{ACKNOWLEDGEMENTS}

We thank Fundo Nacional de Educação e Desenvolvimento (FNDE) and Instituto Federal de Educação, Ciência e Tecnologia Baiano (IF Baiano) for assisting with the data to support this study and Fundação de Amparo à Pesquisa do Estado de Minas Gerais (FAPEMIG) Project APQ-00243-18.

\section{DECLARATION OF CONFLICT OF INTERESTS}

The authors declare no conflict of interest. The founding sponsors had no role in the design of the study; in the collection, analyses, or interpretation of data; in the writing of the manuscript, and in the decision to publish the results. 


\section{AUTHORS' CONTRIBUTIONS}

All authors contributed equally for the conception and writing of the manuscript. All authors critically revised the manuscript and approved of the final version.

\section{REFERENCES}

AGUIAR, J. D. A.; CALIL, R. M. Análise e avaliação das especificações dos alimentos contidas em editais de chamadas públicas do PNAE. Vigilância Sanitária em Debate: Sociedade, Ciencia e Tecnologia, vol. 4, n.2, p.79-87, 2016. Available from: $<$ http://periodicos.fiocruz.br/pt-br/publicacao/1089295>. Accessed: Dec. 04, 2018. doi: 10.3395/2317-269x.00580.

ASSIS, S. C. R. et al. Impacto do Programa de Aquisição de Alimentos na Segurança Alimentar e Nutricional dos agricultores. Ciência \& Saúde Coletiva. vol.22, n.2, p.617-626. 2017, Available from: <http://www.scielo.br/pdf/csc/v22n2/14138123-csc-22-02-0617.pdf>. Accessed: Sep. 27, 2018. doi: $10.1590 / 1413-81232017222.02292015$.

BELIK, W.; SOUZA, L. R. Algumas reflexões sobre os programas de alimentação escolar na América Latina. Planejamento e Políticas Públicas, n.33, p.103-122, Jul./dez. 2009. Available from: $<$ http://ipea.gov.br/ppp/index.php/PPP/article/view/155/171>. Accessed: Nov. 11, 2018

BELIK, W. Perspectivas para segurança alimentar e nutricional no Brasil. Saúde e Sociedade, v.12, n.1, 2003. Available from: <https://www.revistas.usp.br/sausoc/article/ view/7087>. Accessed: Mar. 14, 2018. doi: 10.1590/S010412902003000100004 .

BRASIL. Lei no 11.892, de 29 de dezembro de 2008. Institui a Rede Federal de Educação Profissional, Científica e Tecnológica, cria os Institutos Federais de Educação, Ciência e Tecnologia, e dá outras providências. 2008.

CARVALHO, I. S. H. Potenciais e limitações do uso sustentável da biodiversidade do cerrado: um estudo de caso da Cooperativa Grande Sertão no Norte de Minas. Revista Brasileira de Agroecologia. v.2, n.2, Sep. 2007. Available from: <http:// revistas.aba-agroecologia.org.br/index.php/rbagroecologia/article/ view/6774>. Accessed: Sep. 04, 2018.

CHAVES, L. G. et al. O programa nacional de alimentação escolar como promotor de hábitos alimentares regionais. Revista de Nutrição, Campinas, vol.22, n.6, p.857-866, Nov./dez. 2009. Available from: <http://repositorio.unb.br/handle/10482/13944>. Accessed: Mar. 14, 2018.

CIRINO, J. F. et al. Gerenciamento de projetos vinculados ao programa de aquisição de alimentos - doação simultânea em Minas Gerais. Revista de Gestão, São Paulo, Vol.21, n.4, p.451490, Out./dez. 2014. Available from: <https://reader.elsevier.com/ reader/sd/pii/S1809227616302041?token=B4442A5ABA3EE898 9BA182290CDCFEA10C13007ACB99955BD0FFBCC53F2218 C22B63DB0BCB92AC06F6E45003782EF9D9>. Accessed: Jun. 01, 2018. doi: 10.5700/rege541.

COIMBRA, M. et al. Comer e Aprender: Uma História da Alimentação Escolar no Brasil. Belo Horizonte: Instituto Nacional de Alimentação Escolar, Ministério da Educação e Cultura, 1982.
CORRÊA, R. S. et al. Atuação do nutricionista no programa nacional de alimentação escolar na região Sul do Brasil. Ciência \& Saúde Coletiva, Rio de Janeiro, vol.22, n.2, p.563-574, 2017. Available from: <http://www.scielo.br/pdf/csc/v22n2/1413-8123csc-22-02-0563.pdf>. Accessed: Sep. 20, 2018. doi: 10.1590/141381232017222.09622016 .

COSTA, P. M. Gestão e execução do programa nacional de alimentação escolar nos institutos federais de Educação, ciência e tecnologia. 2015. 118f. Dissertação (Nutrição e Saúde) Universidade Federal de Goiás, Goiânia, 2015.

DINIZ, R. F. et al. A Emergência dos mercados institucionais no espaço rural brasileiro: agricultura familiar e segurança alimentar e nutricional. Geo UERJ, Rio de Janeiro, n.29, p.234-252, 2016. Available from: <https://www.e-publicacoes.uerj.br/index.php/ geouerj/article/view/19161/19566>. Accessed: Sep. 21, 2018. doi: 10.12957/geouerj.2016.19161.

FORMIGA, W. A. M. et al. Viabilidade da incorporação do mel de abelha em sachê na alimentação escolar de uma instituição de Ensino de São Domingos-PB . Revista de Agroecologia e Desenvolvimento Sustentável, v.10, n.2, p.79-83, 2015. Available from: <https:// www.gvaa.com.br/revista/index.php/RVADS/article/view/3467>. Accessed: Sep. 19, 2018. doi: 10.18378/rvads.v10i2.3467.

FRANÇA, C.G, et. al. El censo agropecuário 2006 y la agricultura familiar en Brasil. Brasília: MDA, 2009. 95p. Available from: $<$ http://www.nead.gov.br/portal/nead/nead-debate/>. Accessed: Mar. 21, 2018.

GONÇALVES, H. V. B. et al. Family farming products on menus in school feeding: a partnership for promoting healthy eating. Ciência Rural, Santa Maria, vol.45, n.12, 2015. Available from: <http://www.scielo.br/scielo.php?pid=S010384782015001202267\&script=sci_arttext $>$. Accessed: Nov. 10, 2018. doi: 10.1590/0103-8478cr20150214.

GRISA, C. et al. Contribuições do Programa de Aquisição de Alimentos à segurança alimentar e nutricional e à criação de mercados para a agricultura familiar. Revista Agriculturas, v.8, n.3, Set. p.34-41, 2011. Available from: <http://aspta.org.br/wpcontent/uploads/2011/11/artigo-6.pdf $>$. Accessed: Apr. 01, 2018.

GRISA, C.; SCHNEIDER, S. Três gerações de políticas públicas para a agricultura familiar e formas de interação entre sociedade e estado no Brasil. Revista de Economia e Sociologia Rural, Vol.52, Sup.1, p.5125-5146, 2014. Available from: <http://www. scielo.br/pdf/resr/v52s1/a07v52s1.pdf>. Accessed: Nov. 02, 2018. doi: 10.1590/S0103-20032014000600007.

HIRATA, A. R. et al. Secretaria de Educação Profissional e Tecnológica, Instituto Federal de Educação, Ciência e Tecnologia do Sul de Minas Gerais: manual de gestão do PNAE para os Institutos Federais. Pouso Alegre: IFSUL DE MINAS, 2017. 92p.

MALUF, R. S. Abastecimento alimentar, inflação de alimentos e o contexto urbano no Brasil. Questões Agrárias, Agrícolas e Rurais: Conjunturas e Politicas Públicas. Rio de Janeiro: Editora E-papers, 2017. 1v.

MELÃO, I. B. Produtos sustentáveis na alimentação escolar: o PNAE no Paraná. Caderno IPARDES - Estudos e Pesquisas, Curitiba, v.2, n.2, p.87-105, Jul./dez. 2012. Available from: < http:// www.ipardes.pr.gov.br/ojs/index.php/cadernoipardes/article/ view/533/714>. Accessed: Sep. 23, 2018. 
MELO, M. N. T. et al. Sustentabilidade de um programa de alimentação escolar bem-sucedido: estudo de caso no Nordeste do Brasil. Ciência \& Saúde Coletiva, v.21, n.6, p.18991908, 2016. Available from: <http://www.scielo.br/scielo. php?script $=$ sci_arttext\&pid=S1413-81232016000601899\&lng=pt\& nrm $=$ iso\&tlng $=$ pt $>$. Accessed: Sep. 27, 2018. doi: 10.1590/141381232015216.08752016 .

MIRANDA, D.; GOMES, B. National program of fortification for family farming: trajectories and challenges at the Ribeira Valley, Brazil. Sociedade \& Natureza, Uberlândia, v.28, n.3, p.397-408, 2016. Available from: <http://www.scielo. br/scielo.php?pid=S1982-45132016000300397\&script $=$ sci arttext\&tlng=pt $>$. Accessed: Sep. 27, 2018. doi: 10.1590/1982451320160306.

MONTEIRO, C. A. A dimensão da pobreza da desnutrição e da fome no Brasil. Estudos Avançados, São Paulo, v.17, n.48, May./Aug. 2003. Available from: <http://www.scielo.br/scielo. php p pid $=$ S0103-40142003000200002\&script $=$ sci arttext $>$. Accessed: Sep. 23, 2018. doi: 10.1590/S0103-40142003000200002.

OLIVEIRA, L.G; et al. Comparative assessment of the food purchase program and the national school feeding program's impact in Ubá, Minas Gerais, Brazil. Ciência Rural, v.47,n.1.p.1-7. 2017. Available from: <http://www.scielo.br/scielo.php?pid=S0103$84782017000100932 \&$ script $=$ sci_abstract\&tlng $=\mathrm{pt}>$. Accessed: Jul. 12, 2018. doi: 10.1590/0103-8478cr20160395.

PEDRAZA, D. F; et al. Avaliação do Programa Nacional de Alimentação Escolar: revisão da literatura. Ciência \& Saúde Coletiva, Rio de Janeiro, v.23, n.5, p.1551-1560, 2018. Available from: <http://www.scielo.br/pdf/csc/v23n5/1413-8123csc-23-05-1551.pdf > . Accessed: Jan. 04, 2019. doi: 10.1590/141381232018235.17832016 .

PEIXINHO, A. M. L. A trajetória do Programa Nacional de Alimentação Escolar no período de 2003-2010: relato do gestor nacional. Ciência \& Saúde Coletiva, Rio de Janeiro, v.18, n.4, p.909-916, 2013. Available from: <http://www.scielo.br/pdf/csc/ v18n4/02.pdf>. Accessed: Dec. 21, 2018. doi: 10.1590/S141381232013000400002 .

PIPITONE, M. A. P.; et al. Atuação dos conselhos municipais de alimentação escolar na gestão do Programa Nacional de Alimentação Escolar. Revista de Nutrição, Campinas, v.16, Supl. 2, p.143-154, April/June. 2003. Available from: $<$ http://www.scielo.br/scielo.php?script=sci arttext\&pid $=$ S1415-52732003000200001 $>$. Accessed: Nov. 01, 2018. doi: $10.1590 / \mathrm{S} 1415-52732003000200001$

PNP - PLATAFORMA NILO PEÇANHA. Available from: $<$ https:// www.plataformanilopecanha.org/>. Accessed: Aug. 26, 2018.

RIBEIRO. A.L.P. et al. Programa Nacional de Alimentação Escolar (PNAE) e a participação da agricultura familiar em município do Roo Grande do Sul. Revista Gestão e Desenvolvimento em Contexto - GEDECON, v.1, n.1, 2013. Available from: <http:// www.revistaeletronica.unicruz.edu.br/index.php/GEDECON/ article/view/282/222>. Accessed: Oct. 23, 2018.

RESENDE, T. C.; et al. Entre o potencial de transformação local e os entraves do Programa de Aquisição de Alimentos na cidade de Viçosa-MG. Administração Pública e Gestão Social, Viçosa, v.4, p.399-419, 2012. Available from: <https://periodicos.ufv.br/ojs/ apgs/article/view/4081>. Accessed: Oct. 25, 2018. doi: 10.21118/ apgs.v4i4.93.

ROJAS-BUVINICH, D. P. O. Mapeamento da institucionalização dos conselhos gestores de políticas públicas nos municípios brasileiros. Revista de Administração Pública, Rio de Janeiro, v.48, n.1, p.55-82, Jan./fev. 2014. Available from: $<$ http://bibliotecadigital.fgv.br/ojs/index.php/rap/article/ view/16047/14874>. Accessed: Oct. 25, 2018. doi: 10.1590/ S0034-76122014000100003.

SALGADO, R. J. S. F. Implementação do Programa de Aquisição de Alimentos (PAA): a trajetória de operacionalização do PAA institucional na Universidade Federal de Viçosa. 2016, $142 \mathrm{f}$. Dissertação (Administração) - Universidade Federal de Viçosa, Viçosa, 2016

SANTOS, L. M. P., et al. Avaliação de políticas públicas de segurança alimentar e combate à fome no período 1995-2002. 4 Programa Nacional de Alimentação Escolar. Cad Saúde Publica, Rio de Janeiro, v.23, n.11, p.2681-2693, 2007. Available from: $<$ http://www.scielo.br/scielo.php?script=sci arttext\&pid=S0102311X2007001100016>. Accessed: Oct. 13, 2018. doi: 10.1590/ S0102-311X2007001100016.

SCHNEIDER, S.V. F. et al. Potential of Public Purchases as Markets for Family Farming: An Analysis of Brazilian School Feeding Program Between 2011 and 2014. Advances in Food Security and Sustainability, Available from: <https:/www.sciencedirect. com/science/article/pii/S2452263516300039>. v.1, p.69-95, 2016, Accessed: Sep. 01, 2018. doi: 10.1016/bs.af2s.2016.09.003.

TESOURO NACIONAL. Execução orçamentaria. 2018. Available from: <http://www.tesouro.fazenda.gov.br/execucaoorcamentaria> . Accessed: Jul. 26, 2018.

TURPIN, M. E. A alimentação escolar como vetor de desenvolvimento local e garantia de segurança alimentar e nutricional. 2008. 165f. Dissertação (Desenvolvimento Econômico) - Universidade Estadual de Campinas, São Paulo, 2008.

ZIMMERMANN, S. A.; FERREIRA, A. P. El programa de adquisicion de alimentos de la agricultura familiar em MirandibaPE. In: SCOTTO, G. (Org.). Aun hay tiempo para el sol: pobrezas rurales y programas sociales. Brasil - Venezuela Guatemala Una mirada desde lo local. Rio de Janeiro: Actionaid, 2008. p.28-64. 